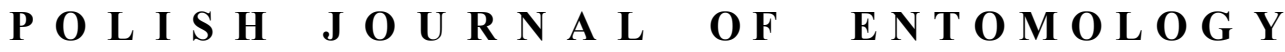

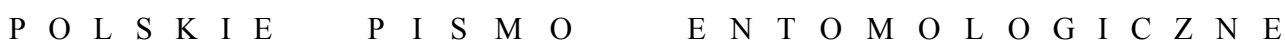

VOL. 82: 151-158

Gdańsk

30 September 2013

DOI: $10.2478 / \mathrm{v} 10200-012-0031-\mathrm{x}$

\section{Life history of Kermes quercus (LinNAEUS) (Hemiptera: Kermesidae) in Poland}

\section{ELŻBIETA PODSIADŁO}

Department of Zoology, Warsaw University of Life Sciences SGGW, Ciszewskiego 8, 02-786 Warszawa, Poland

\begin{abstract}
This research complements the results of a study of the life cycle of Kermes quercus (L.) performed in Poland in 2008-2009. The latest observations were carried out in 2010 from the beginning of March until the end of November. They showed that K. quercus overwintered as $2^{\text {nd }}$-instar nymphs. These developed into adults at the beginning of May. Reproduction began at the beginning of June. The $1^{\text {st }}$-instar nymphs of the new generation appeared in mid-June. They then developed for about 5 months, after which they entered the winter diapause.

All the observations, carried out in 2008-2010, showed that, under the climatic conditions of Poland, K. quercus is not a univoltine species. One generation develops over two years. In the first year it overwinters as $1^{\text {st }}$-instar nymphs and in the second year as $2^{\text {nd }}$-instar nymphs.
\end{abstract}

KEY WORDS: Hemiptera, Kermesidae, Kermes quercus (LINNAEUS), life cycle, developmental stages.

\section{INTRODUCTION}

Kermes quercus (L.) is a Palaearctic species, widespread in many European countries (KoszTARAB \& KozÁR 1988). In Poland it is very common, too (KAWECKI 1985, SIMON \& HERCZEK 2010). It lives mainly in the bark crevices of tree trunks and on thick branches but, at high densities, it can also occur on thinner branches. Locally it can be a serious pest of oaks (NASONOV 1910, KOZÁR 1974, PODSIADŁO 2011). NASONOV was the first author to study the biology of K. quercus, in the region of St Petersburg in 1907 and 1908, but his description of the species' life cycle was not clear. Nevertheless, NASONOV'S observations suggested that $K$. quercus was not a univoltine species. SAAKJANBARANOVA and MuZAFAROV (1972) described the life cycle of $K$. quercus, also from the region of St Petersburg. According to these latter authors, $K$. quercus was a univoltine 
species, overwintering as $2^{\text {nd }}$-instar nymphs. These nymphs moulted in the spring and developed into adults. After mating, the adult females started to lay eggs. The $1^{\text {st }}$-instar nymphs hatched from the eggs and moulted into $2^{\text {nd }}$-instars in August. In the autumn the $2^{\text {nd }}$-instar nymphs entered the winter diapause. A similar description of the life cycle of $K$. quercus was given by SCHMUTTERER from Germany (1972).

Such a scheme of the life cycle of $K$. quercus is generally accepted and is even given on ScaleNet.

Observations carried out in Poland in 2008 and 2009 did not confirm the above version of the life cycle of $K$. quercus (PoDSIADŁo 2011, 2012), however. The present research complements the results of those earlier studies.

\section{Abbreviations}

$\mathrm{L}_{1}-1^{\text {st }}$-instar nymph, $\mathrm{L}_{2}$ 早 $-2^{\text {nd }}$-instar female, $\mathrm{L}_{2}-2^{\text {nd }}$-instar male, $\mathrm{L}_{3}$ - $-3^{\text {rd }}$-instar female, $\mathrm{Pp}$ - prepupa, $\mathrm{P}$ - pupa, + - pre-reproductive female, ${ }^{\circ}{ }^{\circ}$ - reproductive female, ๙ - male.

\section{MATERIAL AND METHODS}

The observations were carried out between the beginning of March and the end of November in 2010. The material was collected on Quercus robur L. in the Bemowo woodland park, situated in the western part of Warsaw.

The mean monthly temperatures for Warsaw in 2010 are given in Table 1.

Table 1. Mean monthly temperatures $\left({ }^{\circ} \mathrm{C}\right.$ ) in Warsaw in 2010 (from the Bulletin of the National Hydrological and Meteorological Service published by the Institute of Meteorology and Water Management in Warsaw, 2010).

\begin{tabular}{|c|c|c|c|c|c|c|c|c|c|c|c|}
\hline Jan. & Feb. & March & April & May & June & July & Aug. & Sept. & Oct. & Nov. & Dec. \\
\hline-8.0 & -1.7 & 4.0 & 9.5 & 13.7 & 17.5 & 21.9 & 20.0 & 12.8 & 6.4 & 6.0 & -5.5 \\
\hline
\end{tabular}

Pieces of bark or smaller branches were cut from the trees and all live individuals of $K$. quercus were picked off. In the laboratory they were preserved in $70 \%$ ethanol and the developmental stages were identified. In addition, the content of the brood chambers in females was inspected from mid-May onwards.

Sampling each month was divided into three ten-day periods: $\mathrm{I}-$ from the $1^{\text {st }}$ to the $10^{\text {th }}$ day of the month, II - from the $11^{\text {th }}$ to the $20^{\text {th }}$ day of the month and III - from the $21^{\text {st }}$ to the $30^{\text {th }}$ day of the month. The material was sampled at least once in each period. 
Unpublished material, collected sporadically in 2008, 2011, 2012 and 2013 was also used. This will be mentioned in the discussion.

The majority of specimens were identified under a stereomicroscope following their preliminary soaking in $10 \%$ aq. $\mathrm{KOH}$ for 24 hours. In case of doubt, the specimens were mounted in glycerine or in balsam and examined at a higher magnification. Tables $2 \mathrm{a}, \mathrm{b}$ give the number of specimens of $K$. quercus examined. The number of adult males was based on the number of empty puparia.

\section{RESULTS}

Table 2 a shows that $K$. quercus overwintered in the $2^{\text {nd }}$ nymphal stage. During March $2^{\text {nd }}$-instar nymphs of both sexes were recorded almost exclusively except for single $1^{\text {st }}$ instar nymphs that had failed to moult in the previous year. Although the latter survived the winter, they became infected by fungi and died. In the last third of March the $2^{\text {nd }}$-instar males produced white puparia in which the prepupae, pupae and adult males were formed.

Moulting began in the first third of April and proceeded rapidly (Table 3). The $2^{\text {nd }}$-instar females moulted into $3^{\text {rd }}$-instar females, and the $2^{\text {nd }}$-instar males into prepupae. The moulting of $3^{\text {rd }}$-instar females into adult females started in the first third of May. Prepupae started to moult into pupae in the last third of April. Males appeared in the first third of May. Mating was observed in the second third of May. During May the adult females produced large quantities of honeydew, which coated the surface of host plants and dribbled down the tree trunks. Eggs were laid in the first and second third of June.

Table 2a. Number of specimens of K. quercus (L.) collected on Quercus robur L. in Warsaw between March and June 2010.

\begin{tabular}{|c|c|c|c|c|c|c|c|c|c|c|c|c|}
\hline \multirow{3}{*}{$\begin{array}{c}\text { Life } \\
\text { stage }\end{array}$} & \multicolumn{12}{|c|}{ Month: 10 day periods } \\
\hline & \multicolumn{3}{|c|}{ March } & \multicolumn{3}{|c|}{ April } & \multicolumn{3}{|c|}{ May } & \multicolumn{3}{|c|}{ June } \\
\hline & $\mathrm{I}$ & II & III & $\mathrm{I}$ & II & III & $\mathrm{I}$ & II & III & $\mathrm{I}$ & II & III \\
\hline $\mathrm{L}_{1}$ & 1 & 1 & 1 & 0 & 0 & 0 & 0 & 0 & 0 & 0 & 0 & \\
\hline $\mathrm{L}_{29}$ & 175 & 95 & 180 & 75 & 7 & 6 & 0 & 0 & 0 & 0 & 0 & \\
\hline $\mathrm{L}_{39}$ & 0 & 0 & 0 & 80 & 93 & 84 & 13 & 0 & 0 & 0 & 0 & \\
\hline$q$ & 0 & 0 & 0 & 0 & 0 & 0 & 75 & 69 & 100 & 37 & 0 & \\
\hline qo $^{\circ}$ & 0 & 0 & 0 & 0 & 0 & 0 & 0 & 0 & 0 & 62 & 120 & 80 \\
\hline $\mathrm{L}_{2 \hat{\delta}}$ & 96 & 24 & 42 & 48 & 16 & 6 & 0 & 0 & 0 & 0 & 0 & \\
\hline $\mathrm{Pp}$ & 0 & 0 & 0 & 10 & 78 & 24 & 0 & 0 & 0 & 0 & 0 & \\
\hline $\mathrm{P}$ & 0 & 0 & 0 & 0 & 0 & 22 & 30 & 0 & 0 & 0 & 0 & \\
\hline 0 & 0 & 0 & 0 & 0 & 0 & 0 & 34 & 52 & 0 & 0 & 0 & \\
\hline $\mathrm{L}_{1}$ & 0 & 0 & 0 & 0 & 0 & 0 & 0 & 0 & 0 & 0 & 100 & 300 \\
\hline
\end{tabular}


Table 2b. Number of specimens of K. quercus (L.) collected on Quercus robur L. in Warsaw between July and November 2010.

\begin{tabular}{|c|c|c|c|c|c|c|c|c|c|c|c|c|c|c|c|}
\hline \multirow{3}{*}{$\begin{array}{c}\text { Life } \\
\text { st. }\end{array}$} & \multicolumn{15}{|c|}{ Month: 10 day periods } \\
\hline & \multicolumn{3}{|c|}{ July } & \multicolumn{3}{|c|}{ August } & \multicolumn{3}{|c|}{ September } & \multicolumn{3}{|c|}{ October } & \multicolumn{3}{|c|}{ November } \\
\hline & I & II & III & I & II & III & I & II & III & I & II & III & I & II & III \\
\hline $\mathrm{L}_{1}$ & 210 & 290 & 300 & 100 & 130 & 225 & 427 & 670 & 875 & 650 & 600 & 350 & 560 & 764 & 769 \\
\hline $\mathrm{L}_{2}$ 우 & 0 & 0 & 0 & 0 & 0 & 0 & 0 & 1 & 1 & 0 & 0 & 0 & 0 & 0 & 1 \\
\hline $\mathrm{L}_{2}$ & 0 & 0 & 0 & 0 & 0 & 0 & 0 & 1 & 1 & 2 & 0 & 0 & 1 & 2 & 1 \\
\hline
\end{tabular}

Table 3. The development of a generation of K. quercus (L.) between March and June 2010 in Warsaw. The number of specimens is expressed as a percentage.

\begin{tabular}{|c|c|c|c|c|c|c|c|c|c|c|c|c|}
\hline \multirow{3}{*}{$\begin{array}{c}\text { Life } \\
\text { stage }\end{array}$} & \multicolumn{12}{|c|}{ Month: 10 day periods } \\
\hline & \multicolumn{3}{|c|}{ March } & \multicolumn{3}{|c|}{ April } & \multicolumn{3}{|c|}{ May } & \multicolumn{3}{|c|}{ June } \\
\hline & I & II & III & I & II & III & I & II & III & I & II & III \\
\hline $\mathrm{L}_{1}$ & $<1$ & $<1$ & $<1$ & 0 & 0 & 0 & 0 & 0 & 0 & 0 & 0 & 0 \\
\hline $\mathrm{L}_{2} \mathrm{O}$ & 64 & 79 & 81 & 35 & 4 & 4 & 0 & 0 & 0 & 0 & 0 & 0 \\
\hline $\mathrm{L}_{3} \circ$ & 0 & 0 & 0 & 38 & 48 & 59 & 9 & 0 & 0 & 0 & 0 & 0 \\
\hline 오 & 0 & 0 & 0 & 0 & 0 & 0 & 49 & 57 & 100 & 37 & 0 & 0 \\
\hline$q^{\mathbf{o}}$ & 0 & 0 & 0 & 0 & 0 & 0 & 0 & 0 & 0 & 63 & 100 & 100 \\
\hline $\mathrm{L}_{2 \hat{\delta}}$ & 35 & 20 & 19 & 22 & 8 & 4 & 0 & 0 & 0 & 0 & 0 & 0 \\
\hline $\mathrm{Pp}$ & 0 & 0 & 0 & 5 & 40 & 17 & 0 & 0 & 0 & 0 & 0 & 0 \\
\hline $\mathrm{P}$ & 0 & 0 & 0 & 0 & 0 & 16 & 20 & 0 & 0 & 0 & 0 & 0 \\
\hline 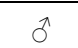 & 0 & 0 & 0 & 0 & 0 & 0 & 22 & 43 & 0 & 0 & 0 & 0 \\
\hline
\end{tabular}

The $1^{\text {st }}$-instar nymphs hatched in the second and last third of June. They developed for about 5 months, after which they entered the winter diapause (Table 2b). In the autumn sporadic moulting of $1^{\text {st }}$-instar nymphs into $2^{\text {nd }}$-instar nymphs was observed, but these made up less than $1 \%$ of the individuals collected. Nearly all the nymphs overwintered as $1^{\text {st }}$ instars.

\section{DISCUSSION}

Tables 4a-e illustrate the development of a generation of $K$. quercus in 2008-2010. As can be seen, adult females started to lay eggs in the first third of June 2008. 
The egg phase lasted about one week. The $1^{\text {st }}$-instar nymphs appeared in the second third of June. They developed for about 5 months, then entered the winter diapause. In autumn 2008 a few $1^{\text {st }}$-instar nymphs moulted into $2^{\text {nd }}$-instars (unpublished data). As later observations showed, these $2^{\text {nd }}$-instar nymphs survived the winter 2008/2009 and even moulted in spring 2009 , but died without reaching sexual maturity. However, as they made up only about $1 \%$ of the individuals collected, nearly all the nymphs overwintered as $1^{\text {st }}$-instars.

In the spring 2009 the $1^{\text {st }}$-instar nymphs became active and continued their development until the last third of August, when they started to moult into the $2^{\text {nd }}$-instar. Hence, the $1^{\text {st }}$ nymphal stage lasted about 14 months. The $2^{\text {nd }}$-instar nymphs developed for about three months before entering the winter diapause. About $1-2 \%$ of the $1^{\text {st }}$-instar nymphs stopped growing and entered the winter diapause in the $1^{\text {st }}$ stage. Most of them died during the winter 2009/2010, although single individuals did survive (see Tables 2a and 3). However, they subsequently became infected by fungi and died. Hence, nearly all the nymphs overwintered as $2^{\text {nd }}$-instars. They did not moult until the end of March, although they were visibly active: for example, $2^{\text {nd }}$-instar males produced puparia. The $2^{\text {nd }}$ instar stage lasted about 7 months.

Moulting started in the first third of April. The $2^{\text {nd }}$-instar females moulted into $3^{\text {rd }}$-instar females, and the $2^{\text {nd }}$-instar males into prepupae. The $3^{\text {rd }}$-instar stage lasted for about one month, mainly during April. The prepupae lasted about 3 weeks and were found in April. The pupae lasted about 2 weeks, being found mainly during the last third of April and the first third of May. Adult males emerged in the first third of May but were hardly noticeable after leaving the puparia except for mating. Their presence was manifested only by the empty puparia. The adult females appeared in the first third of May. They started to lay eggs in the first third of June, thus initiating the development of new generation.

Materials collected sporadically in 2011, 2012 and 2013 confirmed the above life cycle of $K$. quercus in Poland.

Each life stage of $K$. quercus appeared every two years. Adults occurred in evennumbered years: 2008, 2010, 2012.

Dead post-reproductive females can be found attached to the trunks and branches for more than one year and can therefore be collected every year on oaks infested by this species. Likewise, dead nymphs from previous years remain in bark crevices for a long time.

Live females of $K$. quercus produce a viscous honeydew and are therefore easily distinguishable in the field from dead ones.

K. quercus - the northern kermes - probably belongs to the European-Siberian fauna (BoRCHSENIUS 1960). It does not occur in southern Europe. Perhaps the proper development of both $1^{\text {st }}$-instar nymphs and $2^{\text {nd }}$-instar nymphs requires both stages to hibernate. 
Table 4a. The development of a generation of Kermes quercus (L.) in Poland between March and June in 2008 (according to PODSIADŁo 2012).

\begin{tabular}{|c|c|c|c|c|c|c|c|c|c|c|c|c|c|}
\hline \multicolumn{1}{|c|}{ Month: 10 day periods } \\
\hline January & February & \multicolumn{3}{|c|}{ March } & \multicolumn{3}{|c|}{ April } & \multicolumn{3}{c|}{ May } & \multicolumn{3}{c|}{ June } \\
\hline Winter diapause & I & II & III & I & II & III & I & II & III & I & II & III \\
\hline \\
\hline
\end{tabular}

Table 4b. The development of a generation of Kermes quercus (L.) in Poland between July and December in 2008 (according to PODSIADŁO 2012).

\begin{tabular}{|c|c|c|c|c|c|c|c|c|c|c|c|c|c|c|c|}
\hline \multicolumn{3}{|c|}{ July } & \multicolumn{3}{c|}{ August } & \multicolumn{3}{c|}{ September } & \multicolumn{3}{c|}{ October } & \multicolumn{3}{c|}{ November } & December \\
\hline I & II & III & I & II & III & I & II & III & I & II & III & I & II & III & Winter \\
\hline $\mathrm{L}_{1}$ & $\mathrm{~L}_{1}$ & $\mathrm{~L}_{1}$ & $\mathrm{~L}_{1}$ & $\mathrm{~L}_{1}$ & $\mathrm{~L}_{1}$ & $\mathrm{~L}_{1}$ & $\mathrm{~L}_{1}$ & $\mathrm{~L}_{1}$ & $\mathrm{~L}_{1}$ & $\mathrm{~L}_{1}$ & $\mathrm{~L}_{1}$ & $\mathrm{~L}_{1}$ & $\mathrm{~L}_{1}$ & $\mathrm{~L}_{1}$ & diapause \\
\hline
\end{tabular}

Table 4c. The development of a generation of Kermes quercus (L.) in Poland between March and June in 2009 (according to PodSIADŁo 2011).

\begin{tabular}{|c|c|c|c|c|c|c|c|c|c|c|c|c|c|}
\hline \multicolumn{14}{|c|}{ Month: 10 day periods } \\
\hline January & February & \multicolumn{3}{|c|}{ March } & \multicolumn{3}{|c|}{ April } & \multicolumn{3}{|c|}{ May } & \multicolumn{3}{|c|}{ June } \\
\hline \multirow{2}{*}{\multicolumn{2}{|c|}{ Winter diapause }} & I & II & III & I & II & III & I & II & III & I & II & III \\
\hline & & $\mathrm{L}_{1}$ & $\mathrm{~L}_{1}$ & $\mathrm{~L}_{1}$ & $\mathrm{~L}_{1}$ & $\mathrm{~L}_{1}$ & $\mathrm{~L}_{1}$ & $\mathrm{~L}_{1}$ & $\mathrm{~L}_{1}$ & $\mathrm{~L}_{1}$ & $\mathrm{~L}_{1}$ & $\mathrm{~L}_{1}$ & $\mathrm{~L}_{1}$ \\
\hline
\end{tabular}

Table 4d. The development of a generation of Kermes quercus (L.) in Poland between July and December in 2009 (according to PoDSIADŁO 2011).

\begin{tabular}{|c|c|c|c|c|c|c|c|c|c|c|c|c|c|c|c|}
\hline \multicolumn{3}{|c|}{ July } & \multicolumn{3}{|c|}{ August } & \multicolumn{3}{|c|}{ September } & \multicolumn{3}{|c|}{ October } & \multicolumn{3}{|c|}{ November } & December \\
\hline $\mathrm{I}$ & II & III & $\mathrm{I}$ & II & III & I & II & III & I & II & III & I & II & III & \multirow{4}{*}{$\begin{array}{c}\text { Winter } \\
\text { diapause }\end{array}$} \\
\hline \multirow[t]{3}{*}{$\mathrm{L}_{1}$} & $\mathrm{~L}_{1}$ & $\mathrm{~L}_{1}$ & $\mathrm{~L}_{1}$ & $\mathrm{~L}_{1}$ & $\mathrm{~L}_{1}$ & $\mathrm{~L}_{1}$ & $\mathrm{~L}_{1}$ & $\mathrm{~L}_{1}$ & $\mathrm{~L}_{1}$ & & & & & & \\
\hline & & & & & $\mathrm{L}_{2}$ 古 & $\mathrm{L}_{2}$ P & $\mathrm{L}_{2}$ 帛 & $\mathrm{L}_{29}$ & $\mathrm{~L}_{2}$ 우 & $\mathrm{L}_{2}$ P & $\mathrm{L}_{29}$ & $\mathrm{~L}_{29}$ & $\mathrm{~L}_{2}$ 早 & $\mathrm{L}_{2}$ 古 & \\
\hline & & & & & $\mathrm{L}_{20}$ & $\mathrm{~L}_{20}$ & $\mathrm{~L}_{20}$ & $\mathrm{~L}_{28}$ & $\mathrm{~L}_{2 \varnothing}$ & $\mathrm{L}_{2 \gamma}$ & $\mathrm{L}_{2}$ & $\mathrm{~L}_{20}$ & $\mathrm{~L}_{20}$ & $\mathrm{~L}_{2 \lambda}$ & \\
\hline
\end{tabular}


Table 4e. The development of a generation of Kermes quercus (L.) in Poland between March and June in 2010.

\begin{tabular}{|c|c|c|c|c|c|c|c|c|c|c|c|c|c|}
\hline \multicolumn{14}{|c|}{ Month: 10 day periods } \\
\hline January & February & \multicolumn{3}{|c|}{ March } & \multicolumn{3}{|c|}{ April } & \multicolumn{3}{|c|}{ May } & \multicolumn{3}{|c|}{ June } \\
\hline \multirow{9}{*}{\multicolumn{2}{|c|}{ Winter diapause }} & I & II & II & & II & III & I & II & III & $\mathrm{I}$ & II & III \\
\hline & & $\mathrm{L}_{2}$ 古 & $\mathrm{L}_{2}$ 오 & $\mathrm{L}_{2}$ & & $\mathrm{~L}_{2} \mathrm{P}$ & $\mathrm{L}_{2}$ 和 & & & & & & \\
\hline & & & & & & $\mathrm{L}_{39}$ & $\mathrm{~L}_{39}$ & $\mathrm{~L}_{3} \circ$ & & & & & \\
\hline & & & & & & & & q & 우 & q & 우 & & \\
\hline & & & & & & & & & & & $q^{0}$ & $q^{\circ}$ & $\varphi^{0}$ \\
\hline & & $\mathrm{L}_{2 \delta}$ & $\mathrm{L}_{23}$ & $\mathrm{~L}_{2}$ & & $\mathrm{~L}_{28}$ & $\mathrm{~L}_{20}$ & & & & \multirow{4}{*}{\multicolumn{3}{|c|}{$\begin{array}{c}\text { Development } \\
\text { of the next } \\
\text { generation }\end{array}$}} \\
\hline & & & & & & $\mathrm{Pp}$ & $\mathrm{Pp}$ & & & & & & \\
\hline & & & & & & & $P$ & $P$ & & & & & \\
\hline & & & & & & & & 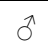 & $\hat{0}$ & & & & \\
\hline
\end{tabular}

\section{CONCLUSIONS}

(1) Under the climatic conditions of Poland, Kermes quercus (L.) is not a univoltine species.

(2) Each generation develops over two years. In the first year it overwinters in the $1^{\text {st }}$ nymphal stage and in the second year in the $2^{\text {nd }}$ nymphal stage.

(3) Each life stage of $K$. quercus appears every two years.

(4) In the study area reproduction took place in the June of even-numbered years.

\section{REFERENCES}

BorChSENIUS N.S. 1960. Fauna of USSR, Homoptera, Coccoidea, Kermococcidae, Asterolecaniidae, Lecaniodiaspididae, Aclerdidae. Akademia Nauk SSSR. Zoologicheskij Institut (N.S. 77) 8: 1-282. [In Russian].

KAWECKI Z.1985. Scale insects, Coccoidea. Catalogue of Polish Fauna. Polish Academy of Sciences, Institute of Zoology 21: 1-108. [In Polish].

Kosztarab M., KozÁr F. 1988. Scale insects of Central Europe. Akadémiai Kiadó, Budapest, pp.: $1-456$.

KozÁr F. 1974. Mass infestation and damage of the oak scale Kermes quercus L. (Homoptera, Coccoidea), Növényvédelem 19: 534-537. [In Hungarian with English, Russian and German summaries].

NASONOV N.V. 1910. On the metamorphosis of Kermes quercus (LinN.), Bulletin de l'Akadémie Impériale des Sciences de St.-Pétersburg 4: 47-60. [In Russian].

PodsiadŁo E. 2011. Study on larval diapause development of Kermes quercus (LinNAEus, 1758 (Hemiptera: Kermesidae) in Warsaw, Poland. Journal of Life Sciences 5: 279-281. 
PodsiadŁo E. 2012. Changes in the body proportions of the 1st-instar nymphs of Kermes quercus (LinNaEus 1758) (Hemiptera: Kermesidae) during growth. Aphids and other hemipterous insects 18: 5-11.

SAAKYAN-BARANOVA A.A., MuZAFAROV S.S. 1972. Structure, biology and interrelationships of northern gall-coccid Kermococcus quercus L. (Homoptera, Kermococcidae) and its parasites (Hymenoptera, Chalcidoidea). Entomologicheskoe Obozrenye 51: 498-519. [In Russian].

SCHMUTTERER H. 1972. Suborder Coccoidea, scale insects. Kermesidae, (Kermidae, Kermococcidae).

[In:] Schwenke W. (ed.). Forest pests of Europe. Paul Parey Publ. Hamburg-Berlin 1: 418-420. [In German].

SCALENET. A Database of the Scale Insects of the World. www.sel.barc.usda.gov/ScaleNet/query.htm Simon E., HerczeK A. 2010. Scale insects (Hemiptera: Coccoidea) of the Landscape Park "Cistercian Landscape Compositions of Rudy Wielkie". Katowice, pp.: 1-127.

Received: 6 June, 2013

Accepted: 4 July, 2013 